Д. 3. Воробець, І. І. Горпинченко, 3. Д. Воробець

Львівський національний медичний університет ім. Данила Галищького Інститут урології АМН України, Київ

\title{
КОРЕЛЯЦІЯ МІЖ ПОКАЗНИКАМИ ПОВ'ЯЗАНОЇ ЗІ ЗДОРОВ'ЯМ ЯКОСТІ ЖИТТЯ І ФОРМОЮ ЕРЕКТИЛЬНОЇ ДИСФУНКЦЇ̈ У ЧОЛОВІКІВ МОЛОДОГО ТА СЕРЕДНЬОГО ВІКУ
}

При психогенній еректильній дисфункції (ЕД) не спостерігається сильних кореляційних зв'язків між доменами анкет SF-36 та МІЕФ. При ЕД внаслідок розвитку ендотеліальної дисфункції, показники доменів загального здоров'я, фізичної функції, відчуття болю та життєвої активності сильно корелюють з усіма доменами опитувань МІЕФ, крім домену задоволення від статевого життя. При ЕД, зумовленій наявністю хронічного тазового болю, показники МІЕФ корелюють із доменами фізичного функціонування, відчуття болю, життєвої активності SF-36. За наявності ЕД, що супроводжує передчасну еякуляцію, показники загального здоров'я, інтенсивності болю та життсвої активності погіршуються та корелюють із загальним балом МІЕФ, доменами сексуального бажання та задоволення від статевого акту.

Д. 3. Воробец, И. И. Горпинченко, 3. Д. Воробец

Львовский национальный медииинский университет им. Данила Галиџкого Институт урологии АМН Украины, Киев

\section{КОРРЕЛЯЦИЯ МЕЖДУ ПОКАЗАТЕЛЯМИ АССОЦИИРОВАННОГО СО ЗДОРОВЬЕМ КАЧЕСТВА ЖИЗНИ И ФОРМОЙ ЭРЕКТИЛЬНОЙ ДИСФУНКЦИИ У МУЖЧИН МОЛОДОГО И СРЕДНЕГО ВОЗРАСТА}

При психогенной эректильной дисфункции (ЭД) не наблюдаются сильные корреляционные взаимосвязи между доменами анкет SF-36 и МИЭФ. При ЭД вследствие развития эндотелиальной дисфункции показатели доменов общего здоровья, физической функции, чувства боли и жизненной активности сильно коррелируют со всеми доменами опросника МИЭФ, кроме домена удовлетворения от половой жизни. При ЭД, обусловленной наличием хронической тазовой боли, показатели МИЭФ коррелируют с доменами физического функционирования, чувства боли, жизненной активности SF-36. При наличии ЭД, сопровождающей преждевременную эякуляцию, показатели общего здоровья, интенсивности боли и жизненной активности ухудшаются и коррелируют с общим баллом МИЭФ, доменами сексуального желания и удовольствием от полового акта.

\author{
D. Z. Vorobets, I. I. Horpynchenko, Z. D. Vorobets \\ Danilo Galitsky Lviv National Medical University \\ Institute of Urology AMS Ukraine, Kyiv
}

\section{CORRELATION BETWEEN LIFE QUALITY INDICES AND A FORM OF ERECTILE DYSFUNCTION IN YOUNG AND MIDDLE-AGED MEN}

The psychogenic erectile dysfunction (ED) does not show strong correlation between domains of questionnaires SF-36 and IIEF. In conditions of ED caused by endothelial dysfunction the domains of general health, physical functioning, bodily pain and vitality strongly correlates with all domains rates of IIEF 
questionnaire except overall satisfaction. In conditions of erectile dysfunction caused by chronic pelvis pain the rates of IIEF correlate with domains of physical functioning, pain, vitality from SF-36. In conditions of premature ejaculation and ED accompaniment the rates of general health, pain intensity and vitality become worth and correlate with total score of IIEF, rates of sexual desire end intercourse satisfaction.

\section{Вступ}

Якість життя (ЯЖ) з побутового терміна перетворилася на предмет клінічної зацікавленості, наукових досліджень, стала показником, за допомогою якого оцінюють ефективність окремих лікарських препаратів, соціально-економічних, медичних програм [12]. ЯЖ - багатогранне системне поняття, яке складається з багатьох компонентів. Виділяють два типи ЯЖ: ті, що стосуються здоров'я (фізична, психологічна, духовна, соціальна функції) та ті, що стосуються чинників впливу на здоров’я (навколишне середовище, економічні, суспільні, політичні чинники). Між ними існують складні зв'язки та розподіл на менші складові та їх компоненти. Медичне втручання впливає на ряд фізичних, фізіопсихоемоційних чинників, а це, у свою чергу, впливає на суспільну та соціальну функцію особи. ВООЗ виділено ряд параметрів ЯЖ, які в основному і вивчаються: фізичні (сила, енергія, втома, біль, дискомфорт, сон, відпочинок), психологічні (позитивні емоції, пам'ять, концентрація уваги, самооцінка, вигляд, негативні переживання), рівень самостійності (буденна активність, працездатність, залежність від лікування та ліків), суспільне життя (взаємовідносини, суспільна цінність суб'єкта, сексуальна активність), навколишнє середовище (благополуччя, безпека, побут, забезпеченість, якість і доступність медичного та соціального забезпечення, доступність інформації, можливість освіти та підвищення кваліфікації, дозвілля, екологія), духовність (релігія, особисті переконання) [3].

Одним із найпопулярніших при проведенні медичних, соціально-економічних досліджень є опитувальник Medical Outcomes Study Short Form 36 (MOS SF-36). Опитувальник перекладений з англійської та російської на українську мову та скорегований 3 досвіду авторів з адаптації SF-36 в Україні [2] та Росії [1]. Також урахована інструкція щодо обробки даних, підготована компанією «Эвиденс-Клиникофармакологические исследования».

Широко розповсюджене загальновизнане твердження, яке грунтується на тривалих спостереженнях клініцистів, що однозначно сексуальна дисфункція пацієнтів негативно відбивається на їхньому фізичному здоров'ї, взаєминах із дружинами, сім'ями та соціумом, проте рідко науковці здійснювали спроби об'єктивізувати ці взаємозв' язки.

Мета даного дослідження - визначити кореляцію показників пов'язаної зі здоров'ям якості життя та показників Міжнародного індексу еректильної функції, залежно від форми ЕД у чоловіків молодого та середнього віку.

\section{Матеріал і методи досліджень}

Дизайн. Дослідження базується на результатах анкетування поліклінічних пацієнтів Львівської обласної консультативної поліклініки та кафедри урології Львівського національного медичного університету ім. Данила Галицького віком від 20 до 40 років. Дослідження проводили з 2004 по 2010 рік, оцінювали результати детального клініко-інструментального, лабораторного обстеження, а також анкетного опитування 182 чоловіків. Серед обстежених - 20 практично здорових добровольців віком 22-38 років, переважно пацієнтів, які звертались у клініку з приводу перевірки фертильності, у процесі всебічного обстеження яких оцінено сексуальну функцію, проведено анкетування за МIEФ та SF-36, не виявлено патоспермії та соматичної патології. 
Анкетування та обстеження також пройшли 163 чоловіки відповідної вікової групи 3 еректильною дисфункцією різної вираженості та генезу.

Застосовувався багаторівневий імовірнісний підхід із прив'язуванням результатів до елементів вибірки. Прив'язування результатів базувалось на групуванні паціснтів за важкістю та формою еректильної дисфункції.

Брали до уваги три критерії для визначення еректильної дисфункції. Питання 16 базувалось на суб’єктивній загальній самооцінці еректильної функції («просте запитання»), та було першим диференційним критерієм різної важкості еректильної дисфункції (ЕД-пз): «Чи вважаєте, що ви чоловік, котрий ... (а) не має проблем з ерекцією; (б) має мінімальні проблеми у досягненні ерекцій; (в) має середньої важкості еректильну дисфункцію; (г) має важке порушення еректильної функції / повну відсутність ерекцій?». Другим критерієм у диференціації важкості ЕД була сума балів відповіді на запитання 1-5 та 15 опитувальника МІЕФ [4; 9], яка формує домен еректильної функції (ЕФ-МІЕФ), згідно з наступною шкалою: 26-30 - немає дисфункції, 17-25 - помірна дисфункція, 11-16 - ЕД середньої важкості, 6-10 - важка ЕД (ED-IIEF). Третій критерій - загальний бал анкети МІЕФ із мінімальним можливим значенням 5 та максимальним 75. Додатковими критеріями враховувались здатність відчувати оргазм - сума балів відповіді на запитання 9 і 10 із можливими значеннями 0-10; підрахунок балів для оцінки сексуального бажання - сума балів відповіді на запитання 11 i 12 із можливими значеннями 2-10; підрахунок балів для оцінки задоволення статевим актом - сума балів відповіді на запитання 6,7 і 8 із можливими значеннями $0-15$; підрахунок балів для оцінки задоволення статевим життям - сума відповідей на запитання 13 і 14 із можливими значеннями 2-10.

Для визначення пов'язаної зі здоров'ям якості життя (ПЗЯЖ) проводили анкетування за допомогою опитувальника SF-36 [8; 11]. Він включає 36 пунктів, які висвітлюють 8 концепцій здоров’я (шкала загального стану здоров'я (33) - оцінка пацієнтом власного стану здоров'я в даний момент і перспектив лікування; фізичного функціонування (ФФ), що відображає, якою мірою здоров'я лімітує виконання фізичних навантажень - самообслуговування, ходьба, підйом по сходах, перенесення вантажу; рольово-фізичне функціонування (РФ) - вплив фізичного стану на рольове функціонування - роботу, виконання повсякденної діяльності; рольово-емоційне функціонування (РЕ) - вплив емоційного стану на рольове функціонування, передбачає оцінку стану, в якому емоційний стан перешкоджає виконанню роботи чи іншої повсякденної діяльності (включаючи збільшення затрат часу, зменшення обсягу виконаної роботи, зниження якості ії виконання тощо); соціальне функціонування (СФ) визначається ступенем, при якому фізичний чи емоційний стан обмежує соціальну активність, спілкування; больові відчуття (БВ) - інтенсивність болю та його вплив на здатність займатись повсякденною діяльністю, включно 3 роботою; життєва активність життєздатність (ЖЗ) включає самопочуття сповненим сил і енергії або навпаки, знесиленим; психічне здоров'я (ПЗ) - самооцінка психічного здоров'я, характеризує настрій (наявність депресії, тривоги, загальний показник позитивних емоцій. Ми не розраховували дві підсумкові компоненти - фізичне та розумове здоров'я через складності та комплексності неавтоматичних обчислень для кожного респондента за відсутності оригінальної програми NSB Calculator із підрахунком цих доменів.

За кожною шкалою SF-36 проведено детальний аналіз, виконано розрахунки статистичних характеристик (дисперсії, середнього значення, стандартного відхилення) для всієї вибірки. Для визначення взаємозв'язків між формою та важкістю ЕД, вирахуваними за доменами МІЕФ та ЕД-пз, а також профілем і компонентами ан- 
кети SF-36, використовували коефіцієнт кореляції. Для встановлення відмінностей між даними SF-36 та показниками анкет МІЕФ і ЕД-пз застосовували $t$-тест Стьюдента (після виконання тесту Фішера - Снедекера на гомоскедастичність вибірок). Для висновків рівень значущості складав 5 \%. Для аналізу даних використовували програмне забезпечення Microsoft Excel 2007 та SPSS 17.

Еректильний домен анкети МІЕФ (запитання 1-5 та 15), анкета ЕД-пз (запитання 16). Список запитань щодо еректильної функції: 1. Як часто вам вдавалось досягти ерекції під час сексуальної активності протягом останніх 4 тижнів? 2. Якщо ви мали ерекції при сексуальній стимуляції, як часто вони були достатньо твердими для пенетрації протягом останніх 4 тижнів? 3. При спробах сексуальної активності, як часто вам вдавалось здійснити пенетрацію протягом останніх 4 тижнів? 4. При сексуальній активності протягом останніх 4 тижнів як часто вам вдавалось підтримувати ерекцію після пенетрації? 5. При сексуальній активності протягом останніх 4 тижнів наскільки важко було підтримувати ерекцію до завершення статевого акту? 6. Скільки раз ви здійснювали спроби статевої активності протягом останніх 4 тижнів? 7. Скільки успішних спроб статевої активності ви завершили протягом останніх 4 тижнів? 8. Наскільки ви задоволені своєю статевою активністю протягом останніх 4 тижнів? 9. Яким відсотком еякуляції завершувалась ваша сексуальна активність протягом останніх 4 тижнів? 10. Як часто ви відчували оргазм або незадоволення (з або без еякуляції) під час статевих контактів протягом останніх 4 тижнів? 11. Як часто у вас виникали сексуальні бажання протягом останніх 4 тижнів? 12. Як ви оцінюєте рівень свого статевого бажання протягом останніх 4 тижнів? 13. Наскільки ви задоволені статевим життям протягом останніх 4 тижнів? 14. Наскільки ви задоволені статевими стосунками 3 партнеркою протягом останніх 4 тижнів? 15. Наскільки ви оцінюєте рівень впевненості в досягненні та підтриманні ерекцій протягом останніх 4 тижнів? 16. Чи бачите ви себе як чоловіка ... (а) без проблем з ерекціями; (б) з мінімальною еректильною дисфункцією; (в) з еректильною дисфункцією середньої важкості; (г) 3 важкою/повною еректильною дисфункцією?

\section{Результати та їх обговорення}

У дослідженні взяли участь 182 чоловіки, при цьому у 89,7 \% (163) виявили певний ступінь ЕД. Серед обстежених у 71 (43,6\%) діагностовано психогенну ЕД із провідним синдромом тривожного очікування сексуальної невдачі (СТОСН); у 36 (22 \%) - ЕД змішаного генезу, - включено хворих з ендотеліальною дисфункцією, метаболічним синдромом, дисліпідемією, гіпертонічною хворобою, IXC, цукровим діабетом, гіпогонадизмом; у 33 (20,2 \%) ЕД змішаного генезу із провідним синдромом хронічного тазового болю, включено пацієнтів із хронічним простатитом II, IIIa, IIIb категорії; 23 (14,1 \%) сексуальну дисфункцію з основною скаргою на передчасну еякуляцію, яка супроводжувала чи була причиною вторинної ЕД.

Нами розраховано взаємозв'язки та виявлено сильну пряму кореляцію між загальним балом МІЕФ та її еректильним доменом, а також слабку, проте вірогідну, кореляцію $з$ доменом задоволення від статевого життя $(t$-критичне - 1,97) (табл. 1$)$. Сильний обернений кореляційний зв'язок спостерігається як між балом ЕД-пз та загальним балом МІЕФ, так і між ЕД-пз та ЕД-МІЕФ.

Той факт, що немає кореляції між показниками оргазмічної функції та задоволення від статевого життя за МІЕФ $(r=-0,06)$, а також між балами еректильного домену та оргазмічної функції МІЕФ ( $r=0,07)$, може свідчити про те, що чоловіки не надто переймаються оргазмічною функцією, більше зосереджуючи увагу на здатності підтриму- 
вати ерекцію, що, мабуть, є більшим мірилом власних можливостей. Для 20 здорових респондентів також проведено кореляційний аналіз, виявлено лише негативну кореляцію між задоволенням від статевого життя та соціальною функцією $\left(r=-0,49, t=2,3, t_{0,05}=2,1\right)$, між задоволенням від статевого життя та больовими відчуттями $(r=-0,53, t=2,6)$, тобто чим менше чоловік задоволений статевим життям, тим гірше його соціальне функціонування. Можливо, це пов'язано із соматичним болем.

Таблиия 1

Кореляційні зв'язки між середніми показниками анкет МІЕФ та ЕД-пз

\begin{tabular}{|l|c|}
\hline \multicolumn{1}{|c|}{ Характеристика } & Коефіцієнт кореляції \\
\hline МІЕФ загальний бал / бал ЕД-МІЕФ & 0,859 \\
\hline МІЕФ загальний бал / 16 запитання & $-0,764$ \\
\hline бал ЕД-МІЕФ / 16 запитання & $-0,871$ \\
\hline МІЕФ загальний бал / задоволення статевим життям & 0,253 \\
\hline бал ЕД-МІЕФ / задоволення статевим життям & 0,209 \\
\hline бал ЕД-МІЕФ /бал оргазмічної функції & 0,073 \\
\hline бал оргазмічної функції / задоволення статевим життям & $-0,062$ \\
\hline
\end{tabular}

При ЕД домен загального здоров'я достовірно корелює з усіма доменами МІЕФ, крім задоволення від статевого життя. Домен фізичної функції корелює із загальним балом МІЕФ, доменами сексуального бажання, оргазмічної функції, задоволення від статевого акту (табл. 2). Зі зростанням балу життєвої активності та відчуття болю достовірно зростають домени сексуального бажання, оргазмічної функції та задоволення від статевого акту.

Табличя 2

Кореляційні зв'язки між середніми показниками анкет МІЕФ, ЕД-пз та SF-36 усіх чоловіків з ЕД $(n=163)$

\begin{tabular}{|c|c|c|c|c|c|c|c|c|}
\hline $\begin{array}{l}\text { Характе- } \\
\text { ристика }\end{array}$ & $\begin{array}{c}\text { Концепція } \\
\text { здоров'я }\end{array}$ & $\begin{array}{c}\text { МІЕФ } \\
\text { загальний } \\
\text { бал }\end{array}$ & $\begin{array}{c}\text { Сексуальне } \\
\text { бажання }\end{array}$ & $\begin{array}{c}\text { Оргазмічна } \\
\text { функція }\end{array}$ & $\begin{array}{c}\text { Задоволен- } \\
\text { ня статевим } \\
\text { актом }\end{array}$ & $\begin{array}{c}\text { Задоволен- } \\
\text { ня статевим } \\
\text { життям }\end{array}$ & $\begin{array}{c}\text { Еректильна } \\
\text { функція }\end{array}$ & $\begin{array}{c}\text { 16-те } \\
\text { запитання }\end{array}$ \\
\hline \multirow{8}{*}{$\begin{array}{c}\text { Коефіцієнт } \\
\text { кореляції }\end{array}$} & 33 & $0,39 *$ & $0,34^{*}$ & $0,29 *$ & $0,36^{*}$ & 0,08 & $0,24 *$ & $-0,24 *$ \\
\hline & $\Phi \Phi$ & $0,28 *$ & $0,28 *$ & $0,43^{*}$ & $0,39 *$ & 0,04 & 0,01 & $-0,04$ \\
\hline & РФ & 0,07 & 0,12 & 0,04 & 0,05 & 0,01 & 0,05 & $-0,02$ \\
\hline & $\mathrm{PE}$ & 0,06 & 0,04 & 0,05 & 0,01 & 0,02 & 0,08 & $-0,10$ \\
\hline & СФ & 0,01 & 0,06 & 0,06 & 0,08 & 0,02 & 0,05 & 0,05 \\
\hline & БB & 0,10 & $0,19^{*}$ & $0,16^{*}$ & $0,36^{*}$ & 0,04 & 0,11 & 0,14 \\
\hline & Ж3 & $0,23 *$ & $0,21 *$ & $0,44^{*}$ & $0,33^{*}$ & 0,02 & 0,01 & 0,00 \\
\hline & П3 & 0,13 & 0,05 & 0,11 & $0,16^{*}$ & 0,07 & 0,07 & 0,03 \\
\hline \multirow{8}{*}{$t$-значення } & 33 & $5,31^{*}$ & $4,57^{*}$ & $3,79 *$ & $4,93^{*}$ & 1,03 & $3,17^{*}$ & $3,10^{*}$ \\
\hline & $\Phi \Phi$ & $3,69 *$ & $3,75^{*}$ & $6,01^{*}$ & $5,42 *$ & 0,50 & 0,15 & 0,50 \\
\hline & РФ & 0,92 & 1,50 & 0,51 & 0,60 & 0,19 & 0,60 & 0,26 \\
\hline & PE & 0,73 & 0,54 & 0,62 & 0,16 & 0,31 & 1,07 & 1,30 \\
\hline & СФ & 0,18 & 0,76 & 0,72 & 0,99 & 0,29 & 0,60 & 0,61 \\
\hline & БB & 1,27 & $2,47^{*}$ & $2,01 *$ & $4,90 *$ & 0,54 & 1,34 & 1,83 \\
\hline & ЖЗ & $3,03^{*}$ & $2,74^{*}$ & $6,27^{*}$ & $4,46^{*}$ & 0,29 & 0,15 & 0,03 \\
\hline & $\Pi 3$ & 1,68 & 0,63 & 1,45 & $2,04 *$ & 0,92 & 0,88 & 0,43 \\
\hline
\end{tabular}

Приміпки: * - дані достовірні при $p<0,05, t_{0,05}=1,97$; концепції здоров'я: 33 - шкала загального стану здоров'я, ФФ фізичне функціонування, РФ - рольово-фізичне функціонування, РЕ - рольово-емоційне функціонування, СФ соціальне функціонування, БВ - больові відчуття, ЖЗ - життєва активність (життєздатність), ПЗ - психічне здоров'я.

Також від зростання середнього показника життєвої активності взаємозалежить зростання загального балу МІЕФ. Психічне здоров'я пацієнта достовірно залежить від задоволення статевим актом. Тобто, із порушенням сексуальної функції пацієнти дос- 
товірно відмічають упадок сил і енергії, порушення загального здоров'я, фізичної функції, що також пов'язано з виникненням больових відчуттів.

У чоловіків із психогенною ЕД виявлено слабкий вірогідний кореляційний взаємозв'язок між балами рольово-фізичного функціонування анкети SF-36 та балами домену оргазмічної функції, загальним балом МІЕФ, балами ЕД-пз, а також між балами загального здоров'я і ЕД-пз; рольового функціонування, зумовленого емоційним станом і задоволення від статевого акту, балами домену життєвої активності та задоволення від статевого життя (табл. 3). Відсутність чіткої корелятивної тенденції в даній групі пацієнтів пояснюється полісиндромністю та різноманітністю психосоціальних особливостей при ЕД, яку ми трактуємо як психогенну.

Кореляційні зв'язки між середніми показниками анкет МІЕФ, ЕД-пз та SF-36

Таблиия 3 чоловіків із психогенною ЕД $(n=71)$

\begin{tabular}{|c|c|c|c|c|c|c|c|c|}
\hline $\begin{array}{c}\text { Характе- } \\
\text { ристика }\end{array}$ & $\begin{array}{c}\text { Концепція } \\
\text { здоров'я }\end{array}$ & $\begin{array}{c}\text { МІЕФ } \\
\text { загальний } \\
\text { бал } \\
\end{array}$ & $\begin{array}{c}\text { Сексуальне } \\
\text { бажання }\end{array}$ & $\begin{array}{c}\text { Оргазмічна } \\
\text { функція }\end{array}$ & \begin{tabular}{|c|} 
Задоволен- \\
ня статевим \\
актом \\
\end{tabular} & \begin{tabular}{|c|} 
Задоволен- \\
ня статевим \\
життям \\
\end{tabular} & \begin{tabular}{|c|} 
Еректильна \\
функція
\end{tabular} & $\begin{array}{c}\text { 16-те } \\
\text { запитання }\end{array}$ \\
\hline \multirow{8}{*}{$\begin{array}{c}\text { Коефіцієнт } \\
\text { кореляції }\end{array}$} & 33 & 0,176 & 0,201 & 0,070 & 0,141 & 0,205 & 0,122 & $-0,243^{*}$ \\
\hline & $\Phi \Phi$ & 0,051 & 0,019 & 0,037 & 0,032 & 0,072 & 0,069 & $-0,179$ \\
\hline & $\mathrm{P} \Phi$ & $0,285^{*}$ & 0,048 & $0,333^{*}$ & 0,122 & 0,085 & 0,207 & $-0,268^{*}$ \\
\hline & $\mathrm{PE}$ & 0,050 & 0,035 & 0,025 & $0,256^{*}$ & 0,154 & 0,024 & $-0,150$ \\
\hline & $\mathrm{C} \Phi$ & 0,161 & 0,077 & 0,124 & 0,015 & 0,167 & 0,191 & $-0,112$ \\
\hline & БВ & 0,021 & 0,099 & 0,144 & 0,041 & 0,069 & 0,131 & $-0,015$ \\
\hline & Ж3 & 0,008 & 0,058 & 0,015 & 0,077 & $0,265^{*}$ & 0,109 & 0,022 \\
\hline & ПЗ & 0,159 & 0,128 & 0,006 & 0,084 & 0,179 & 0,177 & $-0,339 *$ \\
\hline \multirow{8}{*}{$t$-значення } & 33 & 1,482 & 1,707 & 0,587 & 1,184 & 1,739 & 1,019 & $2,085^{*}$ \\
\hline & $\Phi \Phi$ & 0,427 & 0,157 & 0,309 & 0,269 & 0,598 & 0,571 & 1,510 \\
\hline & $\mathrm{P} \Phi$ & $2,471 *$ & 0,395 & $2,938 *$ & 1,023 & 0,712 & 1,757 & $2,308^{*}$ \\
\hline & $\mathrm{PE}$ & 0,415 & 0,294 & 0,205 & $2,201 *$ & 1,299 & 0,200 & 1,261 \\
\hline & $\mathrm{C} \Phi$ & 1,358 & 0,641 & 1,034 & 0,124 & 1,404 & 1,618 & 0,939 \\
\hline & БВ & 0,172 & 0,823 & 1,205 & 0,342 & 0,573 & 1,100 & 0,125 \\
\hline & Ж3 & 0,069 & 0,484 & 0,125 & 0,645 & $2,280^{*}$ & 0,913 & 0,185 \\
\hline & $\Pi 3$ & 1,338 & 1,069 & 0,047 & 0,698 & 1,516 & 1,496 & $2,996^{*}$ \\
\hline
\end{tabular}

Примітки: * - дані достовірні при $p<0,05, t_{0,05}=1,995$; концепції здоров'я - див. табл. 2.

У чоловіків з ЕД змішаного генезу, пов'язаною з переважним розвитком ендотеліальної дисфункції, встановлено чіткий зв'язок домену фізичного функціонування зі всіма складовими анкети МІЕФ, а також з 16-м запитанням. Пряма кореляція виявлена між балами SF-36 загального здоров'я, відчуття болю, життєвої активності, з одного боку, та показниками МІЕФ - загальним балом, доменами оргазмічної функції, еректильної функції, задоволення від статевого акту - $з$ іншого, що підтверджено також кореляцією показників відчуття болю з розвитком еректильної дисфункції згідно ЕД-пз (табл. 4). Отже, розвиток ендотеліальної (еректильної) функції вірогідно пов'язаний із фізичними розладами, погіршенням загального здоров'я, відчуттям болю та втратою життєвої активності.

При розвитку змішаної ЕД, пов'язаної з больовими відчуттями в ділянці тазових органів, показники МІЕФ корелюють із доменами фізичного функціонування, відчуття болю та життевої активності SF-36 (табл. 5). Розвиток ЕД при цьому достовірно пов'язаний із відчуттям болю та погіршенням життєвої активності. 
Кореляційні зв'язки між середніми показниками анкет МIЕФ та SF-36 чоловіків з ЕД змішаного генезу (включено хворих з ендотеліальною дисфункцісю, метаболічним синдромом, дисліпідемією, гіпертонічною хворобою, ІХС, цукровим діабетом, гіпогонадизмом, $n=36$ )

\begin{tabular}{|c|c|c|c|c|c|c|c|c|}
\hline $\begin{array}{c}\text { Характе- } \\
\text { ристика }\end{array}$ & $\begin{array}{c}\text { Концепція } \\
\text { здоров'я }\end{array}$ & $\begin{array}{c}\text { МІЕФ } \\
\text { загальний } \\
\text { бал } \\
\end{array}$ & $\begin{array}{c}\text { Сексуальне } \\
\text { бажання }\end{array}$ & $\begin{array}{c}\text { Оргазмічна } \\
\text { функція }\end{array}$ & $\begin{array}{c}\text { Задоволен- } \\
\text { ня статевим } \\
\text { актом } \\
\end{array}$ & $\begin{array}{c}\text { Задоволен- } \\
\text { ня статевим } \\
\text { життям } \\
\end{array}$ & $\begin{array}{c}\text { Еректильна } \\
\text { функція }\end{array}$ & $\begin{array}{c}\text { 16-те } \\
\text { запитання }\end{array}$ \\
\hline \multirow{8}{*}{$\begin{array}{c}\text { Коефіцієнт } \\
\text { кореляції }\end{array}$} & 33 & $0,477^{*}$ & $0,423^{*}$ & $0,363^{*}$ & $0,529^{*}$ & 0,210 & $0,382^{*}$ & $-0,189$ \\
\hline & $\Phi \Phi$ & $0,742 *$ & $0,481 *$ & $0,594 *$ & $0,586^{*}$ & $0,457^{*}$ & $0,626^{*}$ & $-0,519^{*}$ \\
\hline & РФ & 0,025 & 0,202 & 0,109 & 0,049 & 0,141 & 0,056 & 0,058 \\
\hline & $\mathrm{PE}$ & 0,150 & 0,010 & 0,172 & 0,046 & 0,091 & 0,159 & 0,155 \\
\hline & СФ & 0,027 & 0,075 & 0,061 & 0,104 & 0,115 & 0,025 & 0,152 \\
\hline & БB & $0,623^{*}$ & $0,490^{*}$ & $0,463^{*}$ & $0,555^{*}$ & 0,250 & $0,524^{*}$ & $-0,396^{*}$ \\
\hline & Ж3 & $0,611^{*}$ & $0,476^{*}$ & $0,642 *$ & $0,520^{*}$ & 0,190 & $0,433^{*}$ & $-0,326$ \\
\hline & $\Pi 3$ & 0,248 & 0,143 & 0,264 & 0,244 & $-0,008$ & 0,192 & $-0,177$ \\
\hline \multirow{8}{*}{$t$-значення } & 33 & $3,162^{*}$ & $2,719^{*}$ & $2,590^{*}$ & $3,639^{*}$ & 1,250 & $2,407^{*}$ & 1,120 \\
\hline & $\Phi \Phi$ & $6,455^{*}$ & $3,196^{*}$ & $4,306^{*}$ & $4,221^{*}$ & $2,998^{*}$ & $4,686^{*}$ & $3,539^{*}$ \\
\hline & $\mathrm{P} \Phi$ & 0,144 & 1,201 & 0,639 & 0,284 & 0,829 & 0,329 & 0,340 \\
\hline & $\overline{\mathrm{PE}}$ & 0,887 & 0,056 & 1,019 & 0,266 & 0,536 & 0,940 & 0,916 \\
\hline & СФ & 0,159 & 0,440 & 0,359 & 0,609 & 0,673 & 0,148 & 0,899 \\
\hline & БВ & $4,644 *$ & $3,280^{*}$ & $3,045^{*}$ & $3,892 *$ & 1,509 & $3,590^{*}$ & $2,513^{*}$ \\
\hline & Ж3 & $4,498^{*}$ & $3,155^{*}$ & $4,886^{*}$ & $3,546^{*}$ & 1,127 & $2,801^{*}$ & 2,014 \\
\hline & $\Pi 3$ & 1,495 & 0,845 & 1,594 & 1,466 & 0,046 & 1,143 & 1,046 \\
\hline
\end{tabular}

Примітки: * - дані достовірні при $p<0,05, t_{0,05}=2,032 ;$ концепції здоров’я - див. табл. 2.

Кореляційні зв'язки між середніми показниками анкет МІЕФ, ЕД-пз та SF-36 чоловіків з ЕД змішаного генезу 3 провідним синдромом хронічного тазового болю (включено паціснтів із хронічним простатитом II, IIIa, IIIb категорій, $n=33$ )

\begin{tabular}{|c|c|c|c|c|c|c|c|c|}
\hline $\begin{array}{c}\text { Характе- } \\
\text { ристика }\end{array}$ & $\begin{array}{c}\text { Концепщія } \\
\text { здоров'я }\end{array}$ & $\begin{array}{c}\text { МІЕФ } \\
\text { загальний } \\
\text { бал }\end{array}$ & $\begin{array}{c}\text { Сексуальне } \\
\text { бажання }\end{array}$ & $\begin{array}{c}\text { Оргазмічна } \\
\text { функція }\end{array}$ & $\begin{array}{c}\text { Задоволен- } \\
\text { ня статевим } \\
\text { актом }\end{array}$ & $\begin{array}{c}\text { Задоволен- } \\
\text { ня статевим } \\
\text { життям }\end{array}$ & $\begin{array}{c}\text { Еректильна } \\
\text { функція }\end{array}$ & $\begin{array}{c}\text { 16-те } \\
\text { запитання }\end{array}$ \\
\hline \multirow{8}{*}{$\begin{array}{c}\text { Коефіцієнт } \\
\text { кореляції }\end{array}$} & 33 & 0,023 & $0,372 *$ & 0,104 & 0,043 & 0,010 & 0,031 & $-0,035$ \\
\hline & $\Phi \Phi$ & $0,444 *$ & $0,459^{*}$ & $0,403 *$ & 0,088 & $0,368^{*}$ & $-0,474 *$ & $-0,286$ \\
\hline & РФ & 0,170 & 0,122 & 0,061 & 0,283 & 0,305 & 0,067 & 0,018 \\
\hline & $\mathrm{PE}$ & 0,050 & 0,077 & 0,146 & 0,268 & 0,076 & 0,167 & $-0,019$ \\
\hline & CФ & 0,187 & 0,149 & 0,142 & 0,007 & 0,091 & 0,209 & $-0,196$ \\
\hline & БB & $0,425^{*}$ & 0,133 & 0,107 & 0,138 & 0,270 & $0,380^{*}$ & $-0,339$ \\
\hline & ЖЗ & $0,386^{*}$ & 0,182 & $0,572 *$ & 0,045 & $0,563^{*}$ & $0,476^{*}$ & $-0,320$ \\
\hline & П3 & 0,192 & 0,184 & 0,123 & 0,046 & 0,257 & 0,176 & 0,038 \\
\hline \multirow{8}{*}{$t$-значення } & 33 & 0,130 & $2,231^{*}$ & 0,580 & 0,241 & 0,055 & 0,173 & 0,195 \\
\hline & $\Phi \Phi$ & $2,761^{*}$ & $2,879^{*}$ & $2,453^{*}$ & 0,492 & $2,207 *$ & $2,999^{*}$ & 1,661 \\
\hline & $\mathrm{P} \Phi$ & 0,960 & 0,682 & 0,340 & 1,642 & 1,782 & 0,373 & 0,101 \\
\hline & $\mathrm{PE}$ & 0,277 & 0,432 & 0,822 & 1,547 & 0,425 & 0,943 & 0,105 \\
\hline & CФ & 1,060 & 0,838 & 0,800 & 0,037 & 0,507 & 1,188 & 1,111 \\
\hline & БB & $2,612^{*}$ & 0,745 & 0,600 & 0,778 & 1,560 & $2,286^{*}$ & 2,006 \\
\hline & Ж3 & $2,327^{*}$ & 1,032 & $3,886^{*}$ & 0,253 & $3,790 *$ & $3,013^{*}$ & 1,881 \\
\hline & П3 & 1,088 & 1,044 & 0,688 & 0,254 & 1,479 & 0,996 & 0,210 \\
\hline
\end{tabular}

Примітки: * - дані достовірні при $p<0,05, t_{0,05}=2,040$; концепції здоров’я - див. табл. 2.

При передчасній еякуляції та ЕД достовірно погіршуються та взаємозалежать загальне здоров'я, відчуття болю та життєва активність із загальним балом МІЕФ, балом сексуального бажання та задоволення від статевого акту МІЕФ (табл. 6). Імовірно, вторинний розвиток ЕД при органічній передчасній еякуляції та дисоргазмії пов'язаний із бо- 
льовою симптоматикою $(r=0,673)$ та супутньою втратою життєвої активності $(r=0,677)$. Фізична функція даної групи чоловіків прямо корелює із задоволенням від статевого життя, а психічне здоров'я - із задоволенням від статевого акту.

Таблиия 6

Кореляційні зв'язки між середніми показниками анкет МIEФ та SF-36

чоловіків із передчасною еякуляцією та еректильною дисфункцісю $(n=23)$

\begin{tabular}{|c|c|c|c|c|c|c|c|}
\hline $\begin{array}{c}\text { Характе- } \\
\text { ристика }\end{array}$ & $\begin{array}{c}\text { Концепція } \\
\text { здоров'я }\end{array}$ & $\begin{array}{c}\text { МІЕФ } \\
\text { загальний } \\
\text { бал }\end{array}$ & $\begin{array}{c}\text { Сексуальне } \\
\text { бажання }\end{array}$ & $\begin{array}{c}\text { Оргазмічна } \\
\text { функція }\end{array}$ & $\begin{array}{c}\text { Задоволення } \\
\text { статевим } \\
\text { актом }\end{array}$ & $\begin{array}{c}\text { Задоволення } \\
\text { статевим } \\
\text { життям } \\
\end{array}$ & $\begin{array}{c}\text { Еректильна } \\
\text { функція }\end{array}$ \\
\hline \multirow{8}{*}{$\begin{array}{c}\text { Коефіцієнт } \\
\text { кореляції }\end{array}$} & 33 & $0,492 *$ & $0,558^{*}$ & 0,399 & $0,558^{*}$ & 0,127 & 0,034 \\
\hline & $\Phi \Phi$ & 0,092 & 0,240 & 0,260 & 0,103 & $0,529 *$ & 0,099 \\
\hline & РФ & 0,028 & 0,186 & 0,377 & 0,266 & 0,143 & 0,171 \\
\hline & $\mathrm{PE}$ & 0,049 & $0,443^{*}$ & 0,102 & 0,380 & 0,266 & 0,020 \\
\hline & CФ & 0,198 & 0,185 & 0,261 & 0,378 & 0,230 & 0,134 \\
\hline & БВ & $0,673^{*}$ & $0,550^{*}$ & 0,072 & $0,551^{*}$ & 0,281 & $0,411^{*}$ \\
\hline & Ж3 & $0,677^{*}$ & $0,489 *$ & 0,247 & $0,568 *$ & 0,048 & $0,408^{*}$ \\
\hline & П3 & 0,328 & 0,332 & 0,048 & $0,466^{*}$ & 0,217 & 0,117 \\
\hline \multirow{8}{*}{$t$-значення } & 33 & $2,589 *$ & $3,082^{*}$ & 1,992 & $3,078^{*}$ & 0,585 & 0,156 \\
\hline & $\Phi \Phi$ & 0,425 & 1,131 & 1,234 & 0,474 & $2,857^{*}$ & 0,456 \\
\hline & $\mathrm{P} \Phi$ & 0,127 & 0,867 & 1,864 & 1,264 & 0,662 & 0,797 \\
\hline & $\mathrm{PE}$ & 0,227 & $2,265^{*}$ & 0,471 & 1,882 & 1,266 & 0,093 \\
\hline & CФ & 0,925 & 0,865 & 1,238 & 1,874 & 1,081 & 0,619 \\
\hline & БВ & $4,170 *$ & $3,021^{*}$ & 0,331 & $3,023^{*}$ & 1,342 & $2,063^{*}$ \\
\hline & Ж3 & $4,213^{*}$ & $2,568^{*}$ & 1,169 & $3,164^{*}$ & 0,218 & $2,045^{*}$ \\
\hline & П3 & 1,590 & 1,612 & 0,218 & $2,413 *$ & 1,017 & 0,539 \\
\hline
\end{tabular}

Примітки: * - дані достовірні при $p<0,05, t_{0,05}=2,080$; концепції здоров’я - див. табл. 2.

Існує декілька досліджень якості життя чоловіків з ЕД, в яких застосовані такі ж концепції, анкети та статистика, що дозволяе виконати порівняння. Основні отримані нами результати узгоджуються з подібними, коли також виявляється зв'язок ЕД з погіршенням здоров'я, емоційними проблемами, стресом [7]. Інші дослідження вказують на взаємозв'язок між психологічними особливостями та еректильною дисфункцією - чоловіки з найвищим рівнем подавлення злості, а також ії експресії мають найбільший шанс розвитку помірної чи вираженої ЕД, ніж загальна популяція, так само як і чоловіки з вираженою депресією [5]. Fugl-Meyer зі співавторами [6] виявили, що у чоловіків, які звертаються за медичною допомогою з приводу ЕД та мають низький рівень задоволення від статевого життя, після відповідного лікування рівень задоволення значно зростає. Araujo зі співавторами [10] доповіли про сильний зв'язок між депресією та еректильною дисфункцією у чоловіків середнього віку. Інші цікаві дані $з$ використання анкети IIEF щодо високої соціальної активності при вираженій ЕД відображені в роботах [7]. Важко трактувати ці дані, оскільки вони не відтворені при застосуванні анкет ЕД-пз та МІЕФ. Пояснення може бути подібним до дослідження EDEM: соціальна активність не прив'язується до віку, хоча молодші пацієнти можуть бути менше соціально залученими, ніж старші. Оскільки ступінь ЕД, визначений шляхом анкетування ЕД-пз, не повністю співвідноситься з даними анкетування МІЕФ, пацієнти з помірно вираженою ЕД (за МІЕФ) можуть бути молодшими, ніж чоловіки 3 помірною ЕД (за ЕД-пз).

\section{Висновки}

1. Сильний від'ємний кореляційний зв'язок спостерігається як між ЕД-пз і загальним балом МІЕФ $(r=-0,76)$, так і між ЕД-пз та ЕД-МІЕФ $(r=-0,87)$. 
2. Для всіх респондентів (як хворих ЕД, так і здорових) прослідковуються значущі прямі корелятивні зв'язки між загальним здоров'ям, фізичним функціонуванням, відчуттям болю, життєвою активністю та усіма доменами МІЕФ.

3. Найближче пов'язаними з ЕД показниками анкети SF-36 виявились бали, які відповідали загальному здоров’ю $(r=0,39)$, фізичній функції $(r=0,28)$ за загальним балом МІЕФ, $-0,266$ та $-0,142$ за ЕД-МІЕФ відповідно $(p<0,05)$.

4. Встановлено кореляційні зв'язки між доменами анкет MIEФ та SF-36 залежно від форми ЕД.

\section{Бібліографічні посилання}

1. Популяционные показатели качества жизни по опроснику SF-36 / B. Н. Амирджанова, Д. В. Горячев, Н. И. Коршунов и др. // Научно-практическая ревматология. - 2008. - № 1. C. $36-48$.

2. Фещенко Ю. І. Процедура адаптації міжнародного опитувальника оцінки якості життя MOS SF-36 в Україні. Досвід застосування у хворих бронхіальною астмою / Ю. І. Фещенко, Ю. М. Мостовой, Ю. В. Бабійчук // Укр. пульмонолог. журн. - 2002. - № 3. - С. 9-11.

3. Чучалин А. Г. Качество жизни больных: влияние бронхиальной астмы и аллергического ринита / А. Г. Чучалин, Н. Ю. Сенкевич // Тер. архив. - 1998. - № 9. - С. 53-57.

4. Cappelleri J. C. Diagnostic evaluation of the erectile function domain of the international index of erectile function / J. C. Cappelleri, R. C. Rosen, M. D. Smith // Urology. - 1999. - Vol. 54. - P. 346-351.

5. Melman A. The epidemiology and pathophysiology of erectile dysfunction / A. Melman, J. C. Gingell // J. Urol. - 1999. - Vol. 161. - P. 5-11.

6. On life satisfaction in male erectile dysfunction / A. R. Fugl-Meyer, G. Lodnert, I. B. Branholm et al. // Int. J. Impot. Res. - 1997. - Vol. 9. - P. 141-148.

7. Sexual Dysfunction in the United States. Prevalence and Predictors / E. O. Laumann, A. Paik, R. C. Rosen // JAMA-1999. - Vol. 281, N 6. - P. 537-544.

8. SF-36 health survey manual and interpretation guide / J. E. Ware, K. K. Snow, M. Kosinski, B. Gandek. - Boston (MA) : New England Medical Center, 1983.

9. The International Index of Erectile Function (IIEF): a multidimensional scale for assessment of Erectile Dysfunction / R. C. Rosen, A. Riley, G. Wagner et al. // Urology. - 1997. - Vol. 49. P. 822-830.

10. The relationship between depressive symptoms and male erectile dysfunction: cross-sectional results from the Massachusetts Male Aging Study / A. B. Araujo, R. Durante, H. A. Feldman et al. // Psychosom. Med. - 1998. - Vol. 60. - P. 458-465.

11. Ware J. E. The MOS 36-item short-form health survey (SF-36) I. Conceptual framework and item selection / J. E. Ware, C. D. Sherbourne // Medical Care. - 1992. -Vol. 30, N 6. - P. 473-483.

12. Ware J. E. Quality of Life and Pharmaco-economics in Clinical Trials / J. E. Ware, B. Gandek, S. D. Keller. - Philadelphia : Lippincott-Raven Publichers, 1995. - P. 681-692.

Надійшла до редколегії 17.06.2010 